\title{
СУЧАСНІ ПІДХОДИ ДО ФОРМУВАННЯ МІКРОБІОЛОГІЧНИХ ЗНАНЬ СТУДЕНТІВ ВИЩИХ МЕДИЧНИХ НАВЧАЛЬНИХ ЗАКЛАДІВ
}

О. І. Карбованець

\author{
ДВНЗ “Ужгородський національний університет”
}

\section{MODERN APPROACHES TO FORMATION MICROBIOLOGICAL KNOWLEDGE OF STUDENTS IN HIGHER EDUCATIONAL INSTITUTIONS}

\author{
O. I. Karbovanets
}

\author{
SHEI "Uzhhorod National University"
}

\begin{abstract}
У статті викладено основні підходи до формування знань студентів медичних спеціальностей 3 мікробіології, які включають комплексне використання: групової навчальної діяльності, різнопланової самостійної аудиторної та позааудиторної роботи, проектної технології навчання, роботи студентів у предметному науковому гуртку, що забезпечують вдосконалення традиційної методики навчання мікробіології та позитивно впливають на процес і результат формування знань в умовах розбудови вищої школи.
\end{abstract}

The article deals with the main approaches to the formation of students' knowledge of medical specialties in microbiology that include comprehensive use: such as, group training activities, diverse class and individual work, design technology training of students in scientific groups that provide improvement of traditional methods of teaching microbiology and positively affect the process and result of the formation of knowledge in terms of the development of higher education.

Вступ. Основною метою реформ сучасної вищої медичної освіти в Україні $є$ приведення рівня підготовки студентів, майбутніх фахівців, у відповідність до європейських критеріїв. Це потребує удосконалення підходів до змісту та організації навчання, які полягають в тому, що знання повинні засвоюватись не готові, а здобуватись у процесі навчальної діяльності. Відтак, постає об'єктивна необхідність у принципових змінах конструювання процесу формування знань студентів, майбутніх лікарів, здатних швидко орієнтуватись у складних клінічних ситуаціях, максимально наближених до охорони здоров'я, які базуються на теоретичних й фахових знаннях з дисциплін медико-біологічного циклу, в тому числі і з мікробіології. Знання з мікробіології є затребуваними в професійній діяльності випускника вищого медичного навчального закладу, і від їх засвоєння майбутнім лікарем, стоматологом чи фармацевтом залежить ступінь готовності до практичної діяльності. Тому проблема якісного формування мікробіологічних знань студентів-медиків залишається надзвичайно актуальною і потребує свого ефективного вирішення. Аналіз проблеми дослідження засвідчує, що в теорії та методиці навчання природничих дисциплін питання формування знань здобули розвиток у працях як вітчиз-

(C) О. І. Карбованець няних, так і зарубіжних вчених. Дидактичні аспекти формування знань розкриті у працях В. П. Беспалько, Д. Н. Богоявленського, П. Я. Гальперіна, С. У. Гончаренка, В. В. Давидова, Г. С. Костюка, І. Я. Лернера, А. К. Маркової, Н. О. Менчинської, В. О. Онищука, В. П. Паламарчук, П. І. Підкасистого, І. П. Підласого, Н. Ф. Тализіної, Т. І. Шамової та інших. Однак переорієнтація на європейські стандарти в освіті вимагає постійного вдосконалення шляхів навчання, пошуку нових можливостей для підвищення ефективності формування знань студентів вищих навчальних закладів.

Мета дослідження полягає у визначенні основних сучасних підходів до формування знань студентів медичних спеціальностей у мікробіологічній галузі відповідно до реформування вищої медичної освіти.

Основна частина. Мікробіологія як наука про найдрібніші і найпоширеніші, невидимі для неозброєного ока живі організми вимагає засвоєння знань з: бактеріології, вірусології, імунології, протозоології. Структура знань, що їх повинні засвоїти студенти медичних спеціальностей, розподілена за темами, видами діяльності та змістом знань і завдань. Із точки зору педагогічних досліджень: "Знання - це перевірений практикою результат пізнання діяльності, правильне ії відображення в мисленні людини у вигляді уяв- 
лень, понять, суджень" [1]. Т. О. Ільїна наголошує на тому, що знання є важливим компонентом навчального матеріалу та провідною ланкою в системі навчання, бо тільки знання сприяють виробленню свідомого користування уміннями й навичками [2]. Поширеним є трактування поняття як “відображення об'єктивних характеристик дійсності в свідомості людини" [3]. Психологи, зокрема Н. Ф. Тализіна [4], визначають знання як образи предметів, явищ матеріального світу, які ніколи не існують у голові людини поза якоюсь діяльністю, поза окремими діями. Знання відображають результат пізнавальної діяльності студентів, i їх формування є складним, довготривалим, цілеспрямованим процесом. Формування мікробіологічних знань студентів-медиків відбувається на основі: понять, які забезпечують свідоме розуміння змісту навчального матеріалу; фактів, які формують переконання та вміння відстояти ідеї; законів, які виражають зв'язки між явищами; теорій, що визначають систему методів прогнозування явищ у галузі знань, які потребують всебічного вивчення та усвідомлення. Дидакти та методисти [5, 6, 7] відмічають, що важливе місце у формуванні знань відводиться поєднанню різних форм навчання викладачем. Практика навчання показує, що успішне формування знань зумовлюється різноманітністю чинників та сучасних підходів до особистості. Ключові позиції при цьому займає скерованість студентів-медиків у процесі вивчення мікробіології на діалог та співпрацю в малих групах. Малі навчальні групи соціальними психологами та педагогами (Г. С. Антипіна, О. А. Блажко, С. С. Вітвицька, С. І. Головаха, Л. Десєв, В. К. Дяченко, Я. Л. Коломинський, А. Н. Леонтьєв, Л. Ніколов, Е. Ф. Нор, Б. Д. Паригін, А. В. Петровський, С. Л. Рубінштейн, Г. К. Селевко, Р. А. Хабіб, А. В. Хуторський, І. С. Якиманська, О. Г. Ярошенко) розглядаються як мікросередовище особистості та як суб'єкт спільної діяльності. Основними умовами створення малих груп є їх психологічна сумісність та якісний склад [8]. Студенти-медики в складі малих навчальних груп при вивченні мікробіології працюють за запропонованими викладачем завданнями, що надає можливість працювати з малими групами в аудиторний час самостійно. До використання групової форми роботи на занятті з мікробіології проводиться відповідна підготовча робота, а саме: аналіз змісту навчального матеріалу, перелік базових знань, умінь і навичок, підготовка завдань для роботи в групах. Технологічний процес групової роботи передбачає: 1) підготовку до роботи в групах (постановка пізнавальної проблеми, інструктаж виконання роботи, роз- поділ роздаткового дидактичного матеріалу); 2) навчальну діяльність у складі малих груп (ознайомлення $з$ матеріалом, планування роботи, розподіл завдань у групі, індивідуальне виконання завдань, обговорення, підведення підсумків); 3) заключну частину (оприлюднення результатів роботи в групах, аналіз, висновки про роботу). Групова робота включається в структуру проведення лабораторних занять з мікробіології. Застосовуються також різні моделі групової роботи зі студентами (“Діалог-спільний пошук групами узгодженого рішення"; “Синтез думок”; “Спільний проект” і т. д.). Успішною є робота в гетерогенних групах, де створюються умови для спілкування студентів та розвитку їх комунікативних здібностей.

Результативним компонентом формування знань $\mathrm{i}$ педагогічним новаторством є проектне навчання, яке здатне стимулювати пізнавальний інтерес студентів, забезпечувати зв'язок теорії з практикою та створювати умови для застосування групової форми навчання в позааудиторний час. У проектній діяльності практично реалізуються уміння самостійно здобувати і поповнювати свої знання, які є однією з основних ознак підготовки випускника вищого навчального закладу. Аналіз літератури з проблеми проектної діяльності (Н. В. Альохіна, І. Бем, Й. Шнейдер, І. Г. Срмаков, А. А. Карачев, О. А. Козіна, Д. Г. Левітас, Н. В. Матяш, В. Мигунов, Ю. В. Момот, Н. Ю. Пахомова, П. Петряков, О. М. Пехота, С. С. Полат, Д. О. Пузіков, О. Рибіна, В. Д. Симоненко, С. О. Сисоєва, Ю. Л. Хотунцев, А. В. Хуторський, I. Чечель, Г. І. Щукіна) переконливо доводить іï дієвість у контексті особистісно-орієнтованого підходу до навчання. Суть методу проектів розкривається одним із провідних вчених С. С. Полат: “Метод проектів передбачає сукупність навчально-пізнавальних прийомів, що дозволить вирішити певну проблему під час самостійних дій з обов' язковою презентацією результатів. Якщо говорити про метод проектів як педагогічну технологію, то вона передбачає сукупність дослідницьких методів, творчих за своєю діяльністю" [9]. Досягнення мети при виконанні проектів здійснюється через детальне вирішення проблеми, яка завершується практичним результатом. Виконання студентами-медиками проектів з мікробіології розраховане на визначений термін, протягом якого здійснюється самостійна робота, індивідуальна, парна та групова. Основними вимогами, які ставляться до організації і впровадження в навчальний процес 3 мікробіології проектної технології, є визначення конкретної проблеми, ії мотивація, зміст роботи над нею та діяльність студентів-медиків і викладача. В про- 
цесі роботи над проектами мікробіологічного змісту студенти вчаться самостійно мислити, окреслювати розв'язання проблеми, інтегрувати знання різних навчальних дисциплін, установлювати причинно-наслідкові зв'язки, прогнозувати результати. У студентів розвивається фаховий інтерес до вивчення дисципліни, набуваються почуття успіху й прогресу на власному рівні, виробляються дослідницькі уміння і навички, фахові здібності, засвоюються нові поняття та терміни, формуються знання. Цінність проектів полягає в ефективності застосування їх в освітньому процесі як засобу, який активізує самостійну пізнавальну діяльність, успішно впливає на формування знань.

У навчальній діяльності важливим способом формування самостійності в набутті знань виступає також різнопланова (репродуктивна, евристична, творча) самостійна робота, яка в сучасних умовах розбудови вищої школи знаходиться в центрі уваги вчених та практиків, керівництва вищих навчальних закладів і викладацького складу кафедр. Аналіз психолого-педагогічної літератури (А. М. Алексюк, М. А. Данилов, А. В. Жарова, І. А. Зимня, С. М. Кустовський, І. Я. Лернер, Р. М. Мікельсон, І. Т. Огородников, В. Н. Орлов, П. І. Підкасистий, М. М. Скаткін, М. М. Солдатенко, Р. Б. Срода, Л. В. Туровська, T. I. Шамова) дає підстави стверджувати, що стимулювання самостійної роботи є важливою умовою формування знань. Організація самостійної роботи студентів багато в чому залежить від методики навчання, яка дає змогу навчити їх працювати зацікавлено і самостійно. Тому, враховуючи сказане, з метою підвищення ефективності формування знань студентів медичних спеціальностей з мікробіології, при проведенні занять впроваджується алгоритм виконання завдань як необхідної важливої складової навчального процесу. Структура методики організації та проведення самостійної роботи при проведенні занять 3 мікробіології включає: 1) самостійну роботу, яка вимагає виконання завдань до вивчення теми на занятті: а) завдань міждисциплінарного змісту (базові знання, уміння й навички), які необхідні для вивчення теми (міждисциплінарна інтеграція); б) завдань до змісту теми (рекомендована література основна, додаткова), орієнтовні карти для самостійної роботи з літературою за визначеною темою; в) матеріали для самоконтролю (запитання, тести); 2) аудиторну самостійну роботу: а) навчальні завдання, які необхідно виконати на занятті; б) професійні алгоритми (орієнтовна карта) щодо опанування знаннями, уміннями й навичками; в) навчальні завдання (тести, що доповнюють самостійну роботу на занятті); г) довідкові матеріали; 3 ) позааудиторну самостійну роботу: а) основні завдання, вказівки для самостійної роботи до наступного заняття (підготовка доповідей на визначену тему, рефератів, розробка визначених тем проектів тощо) [10 ]. У процесі організованої таким чином самостійної роботи студенти самі визначають мету діяльності, завдання та проблеми, предмет і засоби діяльності, спрямовані на створення освітнього продукту, що сприяє підвищенню рейтингових показників у навчанні.

Як свідчать літературні джерела з дидактики, знання формуються на різних рівнях, серед яких творчий рівень $€$ найвищим. Формуванню творчого рівня знань студентів медичних спеціальностей сприяють різні чинники, в тому числі й участь у роботі мікробіологічного наукового гуртка, де реалізація інтелектуального потенціалу майбутніх фахівців тісно пов'язана 3 підготовкою спеціалістів, здатних вирішувати не тільки виробничі, але і наукові проблеми в обраній галузі професійної діяльності. Робота гуртка базується на участі студентів, що виявляють інтерес до мікробіології, науково-дослідної діяльності, які стосуються: роз'яснення і прогнозування особливостей перебігу тих чи інших захворювань, що мають важливе значення у збереженні здоров'я людини і які стали глобальною проблемою людства у третьому тисячолітті; формування гіпотез; виконання індивідуально та в малих групах нескладних у підготовці й проведенні дослідів; вирішення ситуаційних задач, 3 допомогою яких студенти логічно оцінюють подані в задачі життєві ситуації i, на основі вивченого, роблять висновки, що дозволяє їм творчо підходити до їх вирішення та підвищувати рівень своїх знань. Проекти, які розробляються студентами-медиками, продовжуються в подальших наукових дослідженнях, а одержані результати і набутий практичний досвід узагальнюються й представляються на студентських наукових конференціях та семінарах. Враховуючи специфіку мікробіологічного матеріалу $[11,12]$, який підлягає вивченню, у зміст роботи гуртка включається інформація, що доповнює та розширює зміст програмового матеріалу, стимулює пізнавальний інтерес до мікробіології взагалі, сприяє підвищенню набутих на заняттях знань, забезпечує їх якісне формування, що підтверджує рівень засвоєння знань 3 навчальної дисципліни “Мікробіологія".

Висновки. Сучасні підходи до формування знань студентів-медиків з мікробіології включають: групову навчальну діяльність, метод проектів, самостійну роботу, науковий гурток, які, будучи поєднані спільною 
метою і завданнями, в комплексі сприяють суттєвому ефективному процесу формування мікробіологічних знань, збільшенню кількості студентів з високими рейтинговими показниками, орієнтують їх на здобуття і використання нових знань. Визначені основні сучасні підходи до формування знань студентів медичних спеціальностей, забезпечують вдосконалення традиційної методики навчання мікробіології, роз- ширюють ії зміст, створюють умови для підвищення рівня їх навчальних досягнень та розвитку творчого потенціалу особистості.

Перспективи подальших досліджень пов'язані із удосконаленням та використанням визначених матеріалів під час фахової підготовки студентів не тільки 3 мікробіології, а й у процесі вивчення інших природничих дисциплін.

\section{Література}

1. Український педагогічний словник / [авт.-уклад. С. У. Гончаренко]. - К. : Либідь, 1997.-376 с.

2. Ильина Т. А. Педагогика: курс лекций / Т. А. Ильина. -

М. : Просвещение, 1984.-496 с.

3. Философия: энциклопедический словарь /под ред.

А. А. Ивина.-М. : Гардарики, 2004.-258 c.

4. Тализіна Н. Ф. Управління процесом засвоєння знань / Н. Ф. Тализіна. - М. : МДУ, 1975.-343 с.

5. Педагогічна майстерність: підруч. / за ред. І. А. Зязюна. - К. : Вища освіта, 2004. - 363 с.

6. Хуторский А. В. Современная дидактика / А. В. Хуторский. -СПб. : Питер, 2001.- 544 с.

7. Чернилевский Д. В. Дидактические технологии в высшей школе / Д. В. Чернилевский. - М. : ЮНИТИ - Дана, 2002. -437 c

8. Ярошенко О. Г. Проблеми групової навчальної діяльності школярів: дидактико-методичний аспект / О. Г. Ярошенко. -К. : Станіца, 1999. - 245 с.

9. Полат Е. С. Новые педагогические и информационные технологии в системе образования / Е. С. Полат. М., 2000.-272 c.

10. Карбованець О. І. Організація самостійної роботи студентів у процесі вивчення мікробіології та ефективність ії використання / О. І. Карбованець // Наук. вісник УжНУ: Серія "Біологія". -2012.-Вип. 33.-С. 89-93.

11. Ситник І. О. Мікробіологія, вірусологія, імунологія / I. О. Ситник, С. І. Климнюк, М. С. Творко. - Тернопіль : Укрмедкнига, 1998.-392 с.

12. Практична мікробіологія / С. І. Климнюк, І. О. Ситник, М. С. Творко, В. П. Широбоков. - Тернопіль : Укрмедкнига, 2004. -440 c.

Отримано 12.05.14 